\title{
PEMETAAN KEBUTUHAN KUALIFIKASI JURNALIS PEMULA PADA INDUSTRI MEDIA MASSA DI INDONESIA
}

\author{
Herlina Agustin, Siti Karlinah, Aceng Abdullah, Dandi Supriadi \\ Program Studi Ilmu Jurnalistik, Fakultas Ilmu Komunikasi, Universitas Padjadjaran
}

\begin{abstract}
ABSTRAK
Ini adalah artikel ilmiah yang membahas kualitas dan sistem seleksi jurnalis pemula di media massa Indonesia saat ini. Artikel ini ditulis berdasarkan hasil penelitian yang dilatarbelakangi kenyataan bahwa banyak jurnalis muda yang melakukan pelanggaran etika maupun teknis ketika sedang meliput. Penelitian yang mendasari artikel ini dilakukan terhadap beberapa media massa cetak, elektronik, dan online di Indonesia. Metode yang digunakan adalah penelitian kualitatif yang melibatkan observasi serta wawancara mendalam. Berdasarkan hasil penelitian, ditemukan bahwa pendidikan ilmu jurnalistik secara umum tidak menjadi pritoritas utama dalam perekrutan jurnalis di media massa yang menjadi objek penelitian kali ini. Hal ini disebabkan media massa tidak merasa bahwa pendidikan jurnalistik dapat menjamin kualitas jurnalis. Hampir di semua media massa, skill jurnalistik yang sesuai dengan karakter media masing-masing dirasakan dapat dilatih secara internal. Kualifikasi yang paling utama adalah adanya passion, loyalty, dan determination dari para kandidiat untuk menjadi jurnalis. Hal-hal itu dinilai dapat diperoleh dari latar belakang pendidikan apapun. Namun demikian semua media sepakat, pendidikan jurnalistik harus menjadi standar bagi kompetensi jurnalis. Maka berdasarkan hasil penelitian ini, disarankan agar pendidikan jurnalistik mengembangkan kurikulumnya sehingga mampu untuk memenuhi kebutuhan media massa akan jurnalis yang berkualitas, terutama dalam hal praktis.
\end{abstract}

Kata-kata kunci: Jurnalistik, kualifikasi jurnalis, standar kompetensi wartawan

\section{NOVICE JOURNALISTS QUALIFICATION REQUIREMENTS MAPPING OF MASS MEDIA INDUSTRY IN INDONESIA}

\begin{abstract}
This is an academic article that discusses the qualification and recruitment system of novice journalists in Indonesian mass media today. This article was written based on the research which revealed the fact that many young journalists violated the ethical and technical principles of journalism while covering the news. This research based on print, electronic, and online mass media in Indonesia. The method used was a qualitative study involving observation and in-depth interviews. The results shows that journalism education in general is not a major requirement for mass media in recruiting journalists. The reason is that mass media feel that the education cannot guarantee the quality of journalist. Almost all media in this research convey that an appropriate journalism skills inline with each corporate character can be trained internally. The most important qualification are passion, loyalty, and determination of the candidates to become journalists, which can be obtained from any educational background. However, all media in this research suggest that journalism education should be the standard in evaluating the competence of journalists. Therefore, it can be suggested that journalism education should develop its curriculum in order to meet the qualifications set by the mass media, especially in practical matters.
\end{abstract}

Keywords: Journalism, journalist qualifications, journalists competency standards

Korespondensi: Dr. Herlina Agustin, S.Sos, MT., Program Studi Ilmu Jurnalistik, Fakultas Ilmu Komunikasi, Universitas Padjadjaran, J1. Raya Bandung-Sumedang Km.21.Email: heragustin@yahoo.com 


\section{PENDAHULUAN}

Dunia jurnalistik selalu menjadi bagian tidak terpisahkan dari industri media massa. Keberadaan berita dalam industri ini seakan-akan menjadi sebuah kewajiban sehingga tidak ada satupun media massa yang tidak memiliki program khusus berita. Ujung tombak dari pembuatan berita adalah keberadaan jurnalis yang melakukan kegiatan jurnalistik dari mulai pencarian bahan berita, penulisan, pengeditan, dan publikasi kepada masyarakat.

Jurnalis adalah orang-orang yang seharusnya memiliki kemampuan dan keterampilan untuk mencari informasi dan menyampaikannya dengan baik. Keberhasilan pekerjaan jurnalis dipertanggungjawabkan kepada masyarakat sebagai pihak yang dilayani haknya. Masyarakat adalah bagian dari masyarakat yang memiliki hal untuk mendapatkan informasi yang benar dan berguna. Jurnalis bertugas untuk memenuhi kebutuhan tersebut. Seperti yang dikemukakan Bill Kovach dan Tom Rosenthiel, kewajiban utama jurnalis adalah untuk kebenaran (journalist's first obligation is for the truth) dan kesetiaan utama dari seorang jurnalis adalah kepada masyarakat (journalist's first loyalty is to citizen). Dengan tugas seperti itu, maka pekerjaan jurnalistik haruslah dilakukan dengan profesional. Sebagai profesi, jurnalis harus memiliki pengetahuan khusus (special knowledge)dan keterampilan (skills).

Dengan rumusan karakteristik seperti di atas, maka tuntutan masyarakat akan pekerjaan jurnalistik yang profesional dan memperjuangkan kebenaran demi kepentingan publik pasti terjawab dengan baik. Namun ternyata pada praktiknya, masyarakat sering mendapatkan bahwa jurnalis sering melakukan kesalahan yang justru merugikan kepentingan publik.

Masyarakat, melalui Dewan Pers dan Komisi Penyiaran Indonesia, telah banyak memberikan pengaduan akibat karya jurnalistik yang dianggap mengganggu kepentingan publik. Gangguan tersebut dapat berupa fakta yang salah, pengemasan yang tidak etis, adanya kelompok masyarakat yang merasa dirugikan atau disudutkan, dan sebagainya.

Banyaknya pengaduan yang diterima Dewan Pers dan KPI menunjukkan bahwa atensi masyarakat akan pekerjaan seorang jurnalis saat ini sudah tinggi. Pengaduan terbanyak adalah yang berhubungan dengan pemberitaan. Artinya, terdapat masalah yang cukup tinggi dalam hal pembuatan karya jurnalistik yang justru merupakan produk utama seorang jurnalis. Dengan kata lain, ada masalah dengan kualifikasi jurnalis yang dipermasalahkan dalam pengaduan tersebut pada saat yang bersangkutan direkrut pertama kali oleh media massa tempat ia bekerja. Tabel berikut merupakan contoh data jenis pengaduan yang diterima Dewan Pers pada tahun 2011 untuk menunjukkan hal tersebut.

Tabel 1 Jenis Pengaduan kepada Dewan Pers

\begin{tabular}{|c|c|c|}
\hline No & Jenis Pengaduan & Jumlah \\
\hline 1 & Mengadukan berita & 67 \\
\hline 2 & Kekerasan terhadap wartawan & 6 \\
\hline 3 & $\begin{array}{l}\text { Mengadukan perilaku } \\
\text { wartawan }\end{array}$ & 10 \\
\hline 4 & Menghalangi wartawan & 4 \\
\hline 5 & $\begin{array}{l}\text { Pemuatan hak jawab tidak } \\
\text { memuaskan }\end{array}$ & - \\
\hline 6 & Hak jawab tidak dimuat & 4 \\
\hline 7 & $\begin{array}{l}\text { Wartawan/media digugat } \\
\text { karena berita }\end{array}$ & 4 \\
\hline 8 & $\begin{array}{l}\text { UU Pers tidak digunakan oleh } \\
\text { penegak hukum }\end{array}$ & 1 \\
\hline 9 & $\begin{array}{l}\text { Sengketa hak cipta nama } \\
\text { media }\end{array}$ & 1 \\
\hline 10 & Mengadukan kartun & 1 \\
\hline 11 & $\begin{array}{l}\text { Digugat karena menulis surat } \\
\text { pembaca }\end{array}$ & 1 \\
\hline 12 & Tidak terkait pers & 3 \\
\hline 13 & Mengadukan artikel/opini & 1 \\
\hline 14 & $\begin{array}{l}\text { Wartawan mengadukan peme- } \\
\text { catan/pemutusan hubungan kerja }\end{array}$ & 3 \\
\hline 15 & Mengadukan iklan & 2 \\
\hline 16 & Mengadukan surat pembaca & 1 \\
\hline 17 & Mengadukan foto & 1 \\
\hline 18 & $\begin{array}{l}\text { Mengadukan badan hukum } \\
\text { perusahaan pers }\end{array}$ & 2 \\
\hline 19 & $\begin{array}{c}\text { Meminta pendapat sesuai UU } \\
\text { Pers }\end{array}$ & 1 \\
\hline 20 & $\begin{array}{l}\text { Meminta pendapat sesuai etik } \\
\text { jurnalistik }\end{array}$ & 8 \\
\hline 21 & $\begin{array}{l}\text { Pemutusan kerjasama dengan } \\
\text { media }\end{array}$ & 1 \\
\hline 22 & $\begin{array}{l}\text { Mengadukan putusan penga- } \\
\text { dilan }\end{array}$ & 2 \\
\hline
\end{tabular}

Sumber: Dewan Pers - 2011 
Keterangan:

Satu kasus bisa memuat beberapa jenis pengaduan.

Contohnya:

mengadukan berita dan badan hukum pers.

Kenyataan di atas kemudian melahirkan pertanyaan krusial yang mendasari penelitian ini. Pertanyaan itu berbunyi: "Seperti apa sebenarnya kualifikasi yang dibutuhkan oleh media massa dari seseorang yang melamar menjadi jurnalis di media massa tersebut?". Apabila semua media massa mengikuti kriteria ideal seperti dibahas sebelumnya di atas, tentu tidak akan terjadi pengaduan sebanyak itu.

Pertanyaan tersebut menjadi sangat penting untuk diteliti dan dijawab, karena kegiatan jurnalistik adalah sebuah kegiatan yang ditujukan untuk kepentingan publik. Masalah kualifikasi awal akan menentukan apakah seorang jurnalis dapat memenuhi kebutuhan publik atau tidak. Namun lebih jauh dari itu, media massa yang bersangkutan juga memiliki kewajiban untuk menyaring jurnalisnya agar tidak melakukan kesalahan. Itu harus dilakukan oleh media tersebut sejak awal, yaitu sejak jurnalis tersebut masih dalam tahap pemula.

\section{METODE PENELITIAN}

Penelitian yang mendasari artikel ilmiah ini bersifat deskriptif dan menggunakan metode penelitian kualitatif. Penelitian akan dilakukan terhadap objek penelitian berupa media massa di Indonesia. Media massa yang dimaksud adalah media massa cetak (surat kabar atau majalah), radio, televsi, dan media online yang memiliki konten berita cukup banyak.

Setelah dilakukan kontak dengan narasumber, media massa yang kemudian diteliti adalah (1) Media massa cetak: a. Surat kabar nasional yang diwakili Kompas dan Republika, b. Majalah berita nasional yang diwakili Majalah Tempo, dan c. Surat kabar regional atau lokal yang diambil dari Kota Bandung (Galamedia) dan Kota Denpasar (Bali Post). (2) Media radio: a. Radio berita jaringan nasional/publik yang diwakili $R R I$, b. Kantor berita radio yang diwakili KBR $68 \mathrm{H}$, dan Radio berita berbasis lokal yang diwakili PRFM, Global FM Bali, dan Suara Surabaya FM. (3) Media televisi: a. Televisi bersiaran nasional yaitu MNC Group diwakili RCTI, Vivanews Group diwakili ANTV dan SCTV-Indosiar, dan b. Televisi lokal yang diwakili BandungTV dan BaliTV, serta (4) Media online yang diwakili oleh Kompas.com

Data diperoleh melalui beberapa tahap dengan perincian (1) Untuk mengetahui seperti apa kebutuhan media massa akan kualifikasi jurnalis, akan dilakukan observasi atau pengamatan terhadap kinerja jurnalis pemula di berbagai media di beberapa kota di Indonesia. Melalui pengamatan tersebut, akan diketahui kelemahan-kelemahan kinerja jurnalistik yang berujung pada buruknya hasil karya jurnalistik serta sumber yang menjadi penyebabnya. (2) Untuk memperkuat hasil temuan deskriptif dan analisisnya, akan dilakukan wawancara mendalam terhadap penanggungjawab rekruitmen jurnalis atau Divisi Sumber Daya Manusia dari setiap media. dan, (3) Hasil wawancara mendalam dianalisis secara kualitatif oleh diskusi sejawat.

\section{HASIL DAN PEMBAHASAN}

Penelitian lapangan tahap pertama ini dilakukan melalui teknik observasi. Karya yang diobservasi adalah berita di media cetak, radio, televisi, dan media online. Media massa yang diamati tidak dibatasi oleh media-media yang telah diungkapkan di atas, tetapi juga mencakup karya jurnalistik di media massa lain yang setara atau berada dalam satu naungan manajemen dengan media yang menjadi objek penelitian.

Pengamatan terhadap isi program berita Vivanews Group (ANTV dan TvOne), Harian Umum Galamedia, Majalah BeritaMingguan Tempo, Radio PRFM dan Kompas.com dilakukan secara acak. Dari pengamatan ini, ditemukan beberapa kesalahan pada redaksi pemberitaan antara lain yang berkaitan dengan logika bahasa atau kesalahan pengucapan/baca.

Misalnya pada program Kabar Pagi Sabtu (TvOne, 24 Agustus 2013) ada berita tentang seorang wanita yang bunuh diri. Presenter berita itu membacakan narasi sebagai berikut:"... seorang wanita di Jogjakarta mengakhiri hidupnya dari rumahnya...". Penggunaan kata "dari" ini tentunya kurang tepat.

Radio PRFM juga tampak mengalami beberapa masalah dalam hal keberimbangan berita, terutama ketika masa Pemilihan Walikota Bandung. Salah satu kandidat yang kemudi- 
an terpilih, Ridwan Kamil, tampak mendapat dukungan penuh dari PRFM. Hal tersebut tidak tersembunyikan, karena $P R F M$ memiliki cukup banyak program berita yang membahas khusus Ridwan Kamil. Bahkan ada satu program khusus setiap Hari Selasa malam, di mana disajikan sebuah acara Talkshow interaktif dengan menghadirkan Ridwan Kamil sebagai narasumber.

Hal yang serupa terjadi di Kompas.com. Pada tanggal 26 Agustus 2013, Kompas.com merilis berita tentang pencalonan Gubernur DKI Jakarta Joko Widodo menjadi Presiden. Dalam berita yang kemudian diikuti banyak berita lanjutan, terlihat jelas dukungan Kompas.com terhadap Joko Widodo. Dalam hal ini, Kompas.com terlihat memihak kepada salah satu golongan.

Sebelumnya, tepatnya tanggal 30 April 2013, Kompas.com memuat berita tentang sebuah perusahaan yang bergerak dalam bisnis perumahan dan mendapatkan laba banyak. Berita tersebut sangat berbau advertorial, namun dimasukkan ke dalam kategori straight news. Reporter Kompas.com yang kemudian dihubungi via Twitter mengakui sulit untuk membedakan advertorial dengan berita biasa ketika topiknya tentang bisnis retail. Namun sebagai media massa yang bergerak di bidang jurnalistik, hal tersebut merupakan kesalahan yang fatal karena menerobos pagar api (firewall) antara fakta dan iklan.

PT. Tempo Inti Media membawahi beberapa media, di antaranya Majalah Berita MingguanTempo, Koran Tempo, dan Tempo.co. Penerimaan jurnalis di Tempo dilakukan secara berkala dalam periode tertentu. Persyaratan umum calon jurnalis Tempo ialah Sarjana Strata 1 dari berbagai latar belakang keilmuan. Selain itu mereka harus sehat jasmani dan rohani, memiliki kemampuan berbahasa Inggris, mampu bekerja dibawah tekanan, dan tentu saja berkeinginan untuk menjadi jurnalis.

Tempo menilai kualitas lulusan ilmu jurnalistik memiliki kelebihan dari sisi teknis dan pengetahuan etika pers. Kualitas sarjana ilmu komunikasi, khsususnya yang dari jurusan ilmu jurnalistik adalah kemampuan teknis, mereka berada satu tahap di depan calon-calon yang lain. Selain itu, lulusan ilmu jurnalistik juga memiliki kelebihan dalam hal pemahaman etika pers yang sangat penting dalam proses kerja seorang wartawan. Namun yang penting selanjutnya adalah bagaimana setiap calon jurnalis dapat mengembangkan diri sebaik mungkin, apa pun latar belakang pendidikannya.

Mengenai uji kompetensi jurnalis, Tempo memiliki sistem uji kompetensi internal yang berkesinambungan, yakni sepanjang jenjang karir jurnalis yang dievaluasi dalam periode tertentu. Maka dari itu, Tempo tidak berafiliasi dengan lembaga pers manapun dalam mengadakan uji kompetensi. Hal itu dikarenakan Tempomengaku memiliki gaya yang khas, dan tuntutan bagi para jurnalis yang bekerja di Tempo pun lebih besar dibandingkan dengan di media lain. Tempo juga secara rutin menyelenggarakan pelatihan bagi calon reporter dan reporter, serta evaluasi berkala untuk mengetahui kualitas kinerja di setiap bagian redaksi.

Dalam penelitian ini, peneliti mengalami kesulitan untuk mendapatkan akses ke Redaksi Kompas pusat di Jakarta. Kendala kesempatan waktu dari redaksi Kompas dan terbatasnya kontak menjadi alasan utama kesulitan ini. Pada akhirnya peneliti kemudian menghubungi Kompas biro Jawa Barat. Keputusan ini diambil karena kesempatan waktu yang ada, dan juga kepentingan peneliti untuk melihat bagaimana kondisi redaksi di daerah.

Ternyata, hasil penelitian di Jawa Barat ini tidak begitu memuaskan karena adanya perubahan manajemen di Kompas Gramedia khususnya untuk media cetak. Biro Kompas Jawa Barat pada awalnya merupakan kantor perwakilan daerah yang memiliki otonomi dalam perekrutan jurnalis maupun kebijakan redaksional. Namun sejak 2010, biro daerah dihapuskan dari manajemen Kompas. Wartawan di daerah hanya berfungsi sebagai kontributor daerah, di mana kebijakan redaksional semua langsung berpusat di kantor pusat Kompas Jakarta.

Proses perekrutan terhadap calon jurnalis di harian Kompas dilakukan di bawah koordinasi Human Resources Departement (HRD) pusat. Proses ini dilakukan secara berkala sesuai dengan program yang sudah ditetapkan. Adapun teknis perekrutannya, HRD yang berada di kantor pusat harian Kompas di Jakarta dapat bekerja sama dengan setiap biro yang tersebar di sejumlah daerah. Misalnya pada saat perekrutan untuk jurnalis di wilayah Jawa 
Barat, semua proses perekrutan dilakukan oleh tim HRD tapi teknisnya dibantu oleh kantor Biro Jawa Barat yang notabene berada di Kota Bandung. Namun keputusan tetap menjadi milik kantor pusat.

Berkaitan dengan standar kualifikasi jurnalis yang dibutuhkan oleh harian Kompas, tentu saja ada kualifikasi tertentu selain yang diterapkan secara umum seperti di media lainnya. Namun seperti apa kualifikasi itu, biro Jawa Barat tidak dapat menjelaskan karena dalam hal ini mereka hanya sebagai user. Kualifikasi tersebut sepenuhnya menjadi ketetapan HRD pusat.

Harian Umum Republika merupakan surat kabar dengan skala nasional. Untuk jurnalis muda, Republika menerima jurnalis yang baru saja lulus sekolah (fresh graduate)minimal S1. Tidak ada batasan latar belakang pendidikan jurusan tertentu. IPK juga tidak terlalu tinggi, 2.75, jika terlalu tinggi dikhawatirkan malah membatasi kanditat potensial di awal proses rekruitmen.

Selain kelonggaran di atas, Republika menyaratkan beberapa hal yang wajib. Kemampuan Bahasa Inggris salah satunya. Selain itu aktivitas organisasi juga dipentingkan, karena biasanya aktivis terlatih bersosialisasi, mudah bergaul dan mengenal orang baru, terlatih berargumen, dan cepat beradaptasi dengan situasi baru.

Di antara itu semua, motivasi kandidat jurnalis muda adalah titik kritis. Biasanya jika berasal dari jurnalistik/ilmu komunikasi, motivasi tidak terlalu dipertanyakan. Lain halnya jika kandidat datang dari jurusan lain, motivasinya akan sangat dipertanyakan. Sejauh ini lulusan komunikasi masih paling banyak jumlahnya di Republika.

Dalam hal kualifikasi, Republika tidak menuntut jurnalis muda memiliki wawasan khusus. Generalis pun cukup tidak usah menguasai suatu bidang khusus. Wawasan yang bagus akan menjadi nilai tambah tapi nilai prioritasnya masih di bawah motivasi.

Keahlian teknis jurnalis muda untuk Republika tidak terlalu penting karena bisa ditingkatkan. Pertimbangan utama adalah motivasi dan kemampuan komunikasi. Tidak ada tes khusus untuk menyaring berdasarkan keahlian teknis, kecuali wartawan foto yang dilihat dari portofolio. Jika portofolio tulisan dari blog bagus itu adalah nilai tambah.

Republika menilai kelemahan paling umum dari jurnalis muda adalah motivasi. Saat ini tidak banyak yang ingin jadi wartawan, rata-rata hanya mencari pekerjaan.Kelemahan dari aspek keahlian dianggap masih bisa ditoleransi dan dikembangkan setelah diterima. Kemampuan menulis misalnya diberi waktu untuk berkembang selama satu tahunpertama di masa percobaan.

Republika kemudian melihat, adanya newsroom konvergen seperti yang sedang dibangun di Fikom Unpad sudah bagus. Sekarang ini Indonesia belum memiliki ahli di bidang majalah digital dan media konvergen.

Sehubungan dengan tahun 2015 akan ada pasar bersama Asia, Republika berharap kalau bisa Fikom Unpad menjadi bagian dari PerguruanTinggi yang bisa menjadi lembaga uji kompetensi wartawan. IFRA (Asosiasi Surat Kabar Internasional) tertarik pada risetriset yang berkaitan dengan perilaku pembaca muda, digital platform dan newsroom konvergen.

Bali Post merupakan media cetak lokal di Denpasar Bali yang berada di bawah Bali Post Media Group bersama dengan BaliTV dan GlobalFM. Perekrutan jurnalis pun berlangsung bersama secara konvergen, di mana jurnalis baru akan merasakan bekerja di ketiga format media tersebut.

Kualitas jurnalis baru yang ada selama ini di Bali Post dinilai masih belum ideal. Salah satunya dirasakan adanya gap yang cukup besar antara level pimpinan dengan para reporter baru baik dari segi wawasan maupun idealisme. Terkadang jurnalis bekerja hanya untuk memenuhi kewajiban. Padahal keinginan dari pimpinan seharusnya jurnalis punya tujuan yang lebih. Bahwa jadi wartawan bukan hanya cari makan atau bekerja.

Standar jurnalis yang dibutuhkan oleh Bali Post secara umum sama dengan standar media lainnya yang sudah baku. Namun selain itu ada juga tambahan berupa ilmu terapan. Bali Post menuntut informasi itu tidak hanya sekedar tahu, tapi mengerti secara mendalam sehingga dapat memberi pandangan lebih lengkap.

Dari sisi teknis, Bali Post menilai calon jurnalis yang ada sekarang lebih cepat mengerti akan pengetahuan. Hal ini bisa jadi disebabkan akses terhadap teknologi lebih mudah 
diperoleh sehingga mereka pun dapat dengan mudah mencari pedoman atau membandingkannya dengan apa yang mereka temukan di dunia maya.Namun Bali Post menilai salah satu kelemahan dari calon jurnalis itu adalah kurangnya loyalitas dan disiplin.

Bali Post merupakan satu-satunya media di Provinsi Bali yang sudah mengantongi sertifikat dari Dewan Pers untuk melakukan uji kompetensi jurnalis. Bali Post merupakan satu dari 18 lembaga yang sudah boleh ikut UKJ. Di Bali Post sendiri sudah ada 10 penguji yang sudah pernah menggelar UKW. Saat ini sudah ada sekitar 58 jurnalis di Bali baik yang berasal dari Bali Post maupun dari luar Bali Post yang sudah ikut UKJ dari berbagai tingkatan.

Bali Post menilai pendidikan jurnalistik perlu menambah porsi latihan. Mahasiswa sebaiknya dilatih sejak masih duduk di bangku kuliah dengan fokusnya antara lain dipersiapkan menjadi jurnalis konvergen.Selain itu, berkaca dari kekurangan yang ada selama ini, idealisme tentang jurnalis juga harus secara konsisten diterapkan. Mahasiswa jurnalistik pun sebaiknya diberi banyak pengetahuan tentang hukum, ekonomi, dan pengetahuan lain agar wawasan mereka terus berkembang. Mereka harus sering diajak berdiskusi, latihan ke lapangan sehingga mereka lebih siap saat diterjunkan ke lapangan kelak. Mereka juga berharap bahwa dikemudian hari akan banyak mahasiswa jurnalistik yang magang di Bali Post.

Harian Umum Galamedia adalah surat kabar lokal Kota Bandung yang secara manajemen masih berada di bawah Grup Pikiran Rakyat. Namun Galamedia secara otonom dapat mengatur organisasinya sendiri termasuk dalam hal rekuritmen.

Untuk memenuhi kebutuhan jurnalis, Galamedia menetapkan kualifikasi tertentu. Namun kualifikasi ini tidak terlalu berbeda dengan standar yang umumnya diterapkan di perusahaan lain.Secara umum calon jurnalis yang berminat bekerja di Galamedia bisa berasal dari latar belakang keilmuan apapun. Artinya, Galamedia tidak mengistimewakan jurusan tertentu seperti Ilmu Komunikasi atau Jurnalistik. Yang penting calon jurnalis yang melamar memiliki pendidikan minimal S1, berusia sekitar 20 tahun, kecuali yang cabutan dari media lain yang masih berada di bawah naun- gan grup Pikiran Rakyat.

Dari sejumlah pengalaman melakukan perekrutan selama ini, lulusan perguruan tinggi, termasuk jurnalistik, dinilai memiliki kelebihan dan kekurangan. Kelebihan yang dimiliki antara lain penguasaan terhadap teknologi terutama gadget digital dan internet lebih maju dibandingkan dengan generasi sebelumnya. Begitu pula berkaitan dengan pengetahuan umum, lulusan baru (fresh graduate) sekarang cenderung lebih baik.

Namun penguasaan teknologi ini juga ternyata berdampak pada karakter mereka. Generasi sekarang cenderung lebih malas karena dengan teknologi itu mereka menilai semua bisa dilakukan lebih mudah sehingga mereka menjadi kurang gigih. Karena itu tidak mengherankan jika redaktur di Galamedia sering kesulitan berkoordinasi dengan wartawannya karena mereka jarang datang ke kantor.

Kekurangan lain adalah mereka kurang mendapatkan praktik atau pelatihan saat kuliah dulu. Pelatihan ini bisa berupa simulasi dengan menempatkan mahasiswa sebagai pemimpin redaksi atau redaktur. Dengan begitu mereka tidak hanya berpikir untuk menjadi reporter, tapi juga pemimpin di redaksi.

Keinginan untuk membaca di kalangan mahasiswa juga harus terus ditumbuhkan. Adanya kemudahan teknologi, membuat sebagian besar mahasiswa mencari jalan pintas dan meninggalkan buku.

Sejak berubah status menjadi radio publik, Radio Republik Indonesia atau RRI lama tidak merekrut karyawan di bidang pemberitaan. Namun dua bulan terakhir RRI mulai merekrut kembali tenaga baru di bidang jurnalistik.

Kandidat yang diterima minimum berpendidikan D3. Latar belakang pendidikan apapun bisa direkrut, namun latar belakang komunikasi/jurnalistik menjadi nilai tambah. Demikian juga dengan pengalaman sebagai jurnalis, yang biasanya kemudian membantu kandidat untuk mempermudah lolos seleksi internal.

Kandidat yang kemudian diterima sebagai jurnalis muda diharapkan mampu melakukan reportase siaran langsung melaporkan dari tempat kejadian. Kemampuan membaca berita tidak wajib untuk pemula. Penyiar berita biasanya adalah reporter yang telah berpengalaman,atau kru khusus yang telah dibina lama sebagai penyiar. Faktor utama yang diperha- 
tikan saat rekruitmen adalah bahwa kandidat harus memiliki semangat dan etos kerja yang baik.

Di luar itu semua, RRI tidak menerapkan Standar Kompetensi Wartawan bagi jurnalis pemula. SKW diberlakukan untuk jurnalis yang telah senior atau telah diterima sebagai jurnalis tetap cukup lama. SKW tidak wajib untuk wartawan pemula dan tidak menjadi ukuran untuk merekrut kandidat pelamar.

Suara Surabaya FM atau biasa disebut SS merupakan radio dengan peresentase karya jurnalistik cukup besar dalam siarannya. Rekruitmen di SS didasarkan pada kebutuhan operasional. Kebutuhan ini meliputi kuantitas dan kualitas. Batasan standar kualitas adalah kemampuan dasar yang memungkinkan untuk dikembangkan menjadi jurnalis di $S S$. Lulusan S1 adalah syarat utama $S S$ dalam menerima jurnalis baru.

Latar belakang ilmu komunikasi dan jurnalistik menjadi prioritas utama. Kalaupun ada kandidat di luar ilmu komunikasi atau jurnalistik, syarat minimalnya adalah memiliki pengalaman di kegiatan jurnalistik, baik yang bersifat formal maupun informal. Pengalaman menjadi pertimbangan yang menguntungkan kandidat dan menjadi ukuran kualitas passion kandidat pada kegiatan jurnalistik.

$S S$ melihat adanya kelemahan pada jurnalis muda. Kelemahan utama adalah pada passion dan pemahaman profesi. Tidak banyak kandidat yang secara sadar memilih profesi jurnalis sebagai profesi pilihan mereka. Kelemahan di segi skill teknis dianggap bisa ditolerir karena hal ini masih memungkinkan untuk dibentuk, asalkan urusan passion dan keseriusan untuk menekuni profesi ini masih tinggi.

SS menilai kurikulum jurnalistik harus mampu menjawab tantangan jurnalisme media massa yang aktual sesuai zaman mahasiswa mulai bekerja. Menurut SS, beberapa metodologi dan materi ajar saat ini masih jauh dari realita industri dan aplikasi praktis.

Pendidikan jurnalistik juga sebaiknya sering mengadakan kuliah umum yang menghadirkan pelaku jurnalisme, sehingga mahasiswa lebih memahami implementasi teori ke dalam kegiatan praktis. Selain itu, institusi pendidikan perlu memperkaya literatur jurnalistik, media massa sebagai referensi penelitian atau penyusunan skripsi, dengan buku-buku mutakhir.
$S S$ juga menyarankan agar pendidikan jurnalistik mewajibkan dosen-dosen non-praktisi yang mengajar jurnalisme, melakukan magang di media massa, agar yang diajarkan membumi dan dapat mengaitkanteori dengan praktek secara tepat dan relevan.

GlobalFM Bali berada di bawah manajemen Bali Post Media Group. Jurnalis pemula juga diambil dari para pelamar grup media tersebut. Artinya, kebijakan kualifikasinya sama dengan media-media lain yang berada di grup tersebut, seperti di Bali Post dan BaliTV.

Lulusan pendidikan jurnalistik tidak menjadi prioritas saat ini. Hal ini disebabkan alasan yang juga dikemukakan oleh Bali Post dan BaliTV, yaitu sulitnya mencari lulusan pendidikan jurnalistik yang mau jadi wartawan di Bali.

Secara kualitas, para jurnalis muda dilihat memiliki semangat tinggi dalam melakukan kegiatan kejurnalistikan. Di Bali, berdasarkan pengamatannya, jurnalistik sangat diminati oleh para pelajar tingkat SMA. Hampir di setiap sekolah ada ekstrakulikuler jurnalistik dan menghasilkan karya jurnalistik yang baik. Maka tidak heran apabila jurnalis muda lulusan S1, meskipun bukan berasal dari lulusan pendidikan jurnalistik, memiliki passion yang tinggi.

Jurnalis di GlobalFM, serupa dengan media jurnalistik lainnya, harus memiliki passion dan rasa keingintahuan yang tinggi. Selain itu, sebagai jurnalis radio yang sering berhubungan dengan masyarakat, mereka harus memiliki keberanian karena pekerjaan jurnalis itu beresiko tinggi.

Mekanisme sertifikasi kompetensi wartawan sangat disepakati oleh GlobalFM. Jurnalis GlobalFM sendiri pernah diikutkan dalam proses sertifikasi tersebut, dan hasilnya memuaskan karena setiap jurnalis pada akhirnya mendapatkan sertifikasi dengan kategori sesuai dengan kemampuannya.

Dalam hal kualitas kurikulum pendidikan jurnalistik, disarankan agar kurikulum pendidikan jurnalistik mulai menyoroti masalah keselamatan jurnalis. Ilmu tentang keselamatan jurnalis yang adsa di medialuar negeri dirasakan belum pernah ada di Indonesia. Padahal keselamatan jurnalis merupakan hal penting karena berbicara bukan hanya tentang peliputan di daerah konflik saja, melainkan juga 
berbagai teknik di daerah bencana atau di tempat-tempat berbahaya lainnya.

Khusus untuk di Bali, pendidikan jurnalistik formal seperti di Univetrsitas Padjadjaran sebaiknyamemiliki program untuk melatih calon-calon jurnalis di tingkat SMA. Hal itu diungkapkan mengingat minat yang sangat tinggi dan bakat yang besar di kalangan siswa SMA di bidang jurnalistik. Selama ini pelatihan dilakukan oleh jurnalis-jurnalis yang ada di Bali. Alangkah lebih baik apabila ada kolaborasi antara institusi akademik dan praktisi dalam mengadakan pendidikan jurnalistik dasar untuk tingkat SMA.

PRFM merupakan radio di Bandung yang berada di bawah Grup Pikiran Rakyat. Berbeda dengan Galamedia yang juga merupakan anggota grup yang sama namun memiliki otonomi yang luas, PRFM masih berada di bawah manajemen Dewan Redaksi Pikiran Rakyat. Bahkan PRFM kini memiliki halaman khusus di surat kabar Pikiran Rakyat yang berisi artikel atau berita $P R F M$ dalam versi cetak. Namun demikian, untuk rekruitmen, $P R F M$ memiliki keleluasaan cukup besar untuk melakukannya sendiri walaupun masih harus dipertanggungjawabkan kepada grup.

Di PRFM, kebijakan untuk merekrut kru diserahkan sepenuhnya pada pimpinan divisi masing-masing. Untuk divisi program, kebijakan rekruitmen diserahkan pada pemimpin redaksi, dengan pertanggungjawaban kualitas produk kepada Direktur maupun Dewan Redaksi di Grup Pikiran Rakyat.

Dalam hal kualifikasi pendidikan, PRFM menerima fresh graduate dengan syarat pendidikan formal minimal D3 dengan pertimbangan kemampuan praktisnya. Untuk tingkatan ini, lebih banyak difokuskan untuk posisi pelaksana, tidak pada penanggungjawab. PRFM menilai latar belakang pendidikan berpengaruh besar terhadap kematangan mereka dalam bekerja. Maka, latar belakang pendidikan jurnalistik sangat dipertimbangkan bahkan menjadi prioritas. Meskipun demikian, tidak menutup kesempatan bagi mereka yang berlatar belakang non jurnalistik untuk melamar.

Keterampilan jurnalistik dianggap sebagai sesuatu yang dapat dipelajari dan dikembangkan sambil jalan. Namun loyalitas dan kerja keras jadi catatan penting, yang bisa saja menggugurkan syarat yang lain.
Dalam melihat kemampuan calon jurnalis atau jurnalis muda, PRFM melihat beberapa kelemahan. Yang paling utama adalah kelemahan praktis, khususnya reportase (announcing) dan Wawasan berita, khususnya berita lokal yang jadi konten PRFM.Jika kaitannya dengan wawasan berita atau skill, kelemahan-kelemahan yang ada bisa dilatih sambil berjalan. Dan sudah terbukti demikian. Namun jika yang jadi kendala adalah motivasi dan loyalitas, akan susah untuk dirubah.

Berkaitan dengan pendidikan jurnalistik, Jurnalistik Fikom Unpad dianggap memiliki standar tinggi terhadap lulusannya, sehingga kadang mahasiswanya merasa "tinggi" ketika di lapangan. Mereka kadang sukar untuk mau memulai dari hal terkecil. PRFM juga melihat lulusan jurnalistik matang untuk kemampuan cetak, termasuk menulis naskah siaran.

Kantor Berita Radio $68 \mathrm{H}$ atau KBR68H adalah sebuah kantor berita khusus untuk karya jurnalistik radio. Artinya, KBR68H tidak mengudara secara reguler menggunakan frekuensi publik, melainkan berlaku sebagai provider berita untuk media radio yang ada di Indonesia.

Dalam perekrutannya, KBR68H menerima calon reporter dengan dan tanpa pengalaman. Selama yang bersangkutan sesuai dengan visi dan misi perusahaan, maka besar kemungkinan sang calon reporter akan diterima.

KBR68H menerima lulusan baru atau fresh graduate S1.Secara formal jenjang pendidikan menjadi salah satu prasyarat calon jurnalis. Namun tidak menutup peluang bagi mereka yang memiliki bakat dan pengalaman jurnalistik yang baik untuk diterima. Latar belakang pendidikan jurnalistik tidak selalu menjadi pertimbangan. Saat ini di redaksi $K B R 68 H$, tidak semua berlatar belakang pendidikan jurnalistik. Yang menjadi pertimbangan yang memiliki nilai adalah para calon jurnalis yang sudah punya pengalaman, minimal pers kampus. Dengan adanya pengalaman di pers kampus maka akan memudahkan dan mempersingkat proses pendidikan sebagai jurnalis di KBR68H.

Selain itu, wawasan atau pengetahuan umum yang luas menjadi salah satu pra-syarat mutlak dalam sistem rekrutmen. Bahasa Inggris juga semakin dibutuhkan. Ini karena banyak bahan-bahan liputan yang tersedia dalam Bahasa 
Inggris. Untuk itu dalam sesi wawancara dengan calon jurnalis ada bagian wawancara dalam Bahasa Inggris.

Kemampuan reportase langsung menjadi salah satu syarat untuk menentukan kelayakan seorang caon jurnalis di $K B R 68 H$. Itu sebabnya reportase atau membaca berita menjadi salah satu materi seleksi jurnalis di KBR68H. Lalu, sama halnya dengan reportase, membacakan berita menjadi syarat pengangkatan seorang menjadi jurnalis di $K B R 68 H$.

Jurnalis baru $K B R 68 H$ memiliki beberapa kelemahan, di antaranya yang paling utama adalah kurang membaca koran dan majalah, serta kurang militan dilapangan. Sementara untuk kelemahan di bidang keterampilan lain, seperti tulisan yang masih kurang kuat dalam pemilihan lead, kurang fokus dan kurang tajam, atau cara membaca berita yang sesuai dengan standar KBR68H, merupakan hal yang masih dapat ditolerir dan dikembangkan dalam pelatihan.

Selain itu, KBR68H menyarankan agar semua orang di kampus kembali diajak untuk mulai menggunakan kembali Bahasa Indonesia tertulis dan lisan secara baik dan benar. Kebiasaan ini akan sangat menguntungkan saat sudah berada didunia jurnalistik.

Setiap jurnalis di Rajawali Citra Televisi Indonesia atau RCTI harus memenuhi kemampuan dalam hal hard competency dan soft competency. Hard competency misalnya dalam hal kemampuan teknik jurnalis pemula seperti: menulis, news gathering, reportase, kameramen. Sementara soft competency yang paling penting adalah bagaimana jurnalis dapat membedakan dan menjiwai pekerjaan di berbagai divisi, seperti misalnya tugas jurnalis di lapangan akan berbeda dengan jurnalis presenter, dan lain-lain. Untuk news anchor contohnya, mereka bukan hanya harus bagus dalam hal penampilan di depan kamera, tapi juga memiliki soul terhadap berita yang dibacakannya. Kegigihan, keuletan, kepercayaan diri,kemampuan komunikasi yang baik, kreativitas di lapangan dalam mencari berita adalah bagian dari soft competencies yang harus dimiliki.

Rekruitment di MNC Group, terutama di $R C T I$ diselenggarakan pada waktu-waktu tertentu.MNC Group juga memiliki JobsMNC, saluran lowongan pekerjaan yang dapat ditemukan di website $R C T I$. Seleksi biasanya dilakukan secara internal. Namun sering pula diadakan kerjasama dengan beberapa kampus yang sering disebut campus hearing. Selama ini kerjasama sudah dilaksanakan diBinus, ITB,IISIP, UGM, dan UNPAR. Campus hearing biasanya dilakukan sekitar bulan Februari-Maret atau September-Oktober, dua kali dalam setahun.

Seperti telah diketahui, Indosiar dan SCTV sekarang telah merger di bawah satu manajemen. Namun, meskipun berada dalam satu perusahaan, tingkat kompleksitas karya jurnalistiknya berbeda. Salah satu yang membuatnya berbeda adalah segmentasi penonton. Berdasarkan segmentasi penontonnya, standar kebutuhan penonton SCTV lebih tinggi dari Indosiar, dan ini mempengaruhi standar karya jurnalistik yang akan disampaikan di stasiun televisi masing-masing.

Jurnalis yang diperlukan di SCTV dan Indosiar tidak harus berasal dari pendidikan tinggi jurnalistik. Penampilan fisik dipertimbangkan, tapi hanya untuk posisi tertentu. Sedangkan untuk posisi reporter penampilan tidak terlalu diutamakan. Adapun kemampuan jurnalistik yang lain seperti penguasaan kamera atau kemampuan menulis, akan menjadi nilai nanti jika mereka sudah lulus tes tahap ini.

Standar Kompetensi Wartawan dinilai penting, meski di SCTV dan Indosiar pelaksanaannya masih dalam proses. Memang ke depan, jurnalis itu harus diakreditasi oleh Dewan Pers. Tujuannya untuk menjawab keluhan dari masyarakat tentang banyaknya jurnalis yang tidak profesional. Maka Dewan Pers nanti hanya akan melayani pengaduan tentang wartawan yang belum terakreditasi.

Selama ini ANTV menerapkan standar tersendiri saat melakukan seleksi SDM-nya termasuk kebutuhan akan jurnalis. Pada tingkat wartawan madya misalnya, $A N T V$ sudah melakukan Uji Kompetensi Wartawan (UKW) baik untuk wartawan pada tingkat utama maupun pemula. Setelah itu secara bertahap mereka juga melakukan sertifikasi terhadap wartawan, temasuk kontributor $A N T V$ yang tersebar di berbagai daerah di Indonesia. Sedangkan bagi calon jurnalis atau jurnalis baru dapat melalui proses perekrutan di perusahaan dengan dua cara.

Pertama yaitu melalui program Pro-Hire yaitu program untuk persiapan menjadi karyawan 
tetap dengan masa percobaan selama enam bulan. Kedua melalui program Professional Learning Center - semacam tempat pelatihan di $A N T V$. Dimulai dengan Testing Day yang dimulai dari seleksi psikotes dan interview hingga pengumuman diterima atau tidak untuk ikut program PLC.

Angkatan pertama PLC berakhir pada bulan Oktober. Angkatan pertama ini diikuti sekitar 1.500 pelamar. Setelah diseleksi, yang lolos ada 73 orang dan 12 di antaranya ada di Divisi News. Dari 12 orang itu, 10 di antaranya berasal dari PLC, dua dari Pro-Hire.

Jurnalis yang melalui program Pro-Hire menerima hak mereka sebagai karyawan misalnya gaji, tunjangan kesehatan, dsb. Sedangkan yang berasal dari PLC diberi uang transport Rp 25 ribu perhari, lima hari kerja.

Seluruh program yang ditayangkan di BaliTV berada di bawah koordinasi satu orang Pimpinan Program dan Pemberitaan. Pimpinan Program dan Pemberitaan BaliTV membawahi 67 orang jurnalis yang merangkap sebagai juru kamera. Selain itu BaliTV juga memiliki kontributor di seluruh Indonesia untuk program "Suluh Indonesia" - program berita yang menayangkan peristiwa-peristiwa dari berbagai belahan negeri.

Proses penerimaan jurnalis di BaliTV rata-rata berlangsung dalam periode setahun sekali. Untuk rekruitmen besar, diadakan pelatihan khusus bagi calon jurnalis yang akan didampingi oleh jurnalis senior dan para editor. Penerimaan, calon jurnalis tersebut akan mengikuti pelatihan internal selama tiga hari, yang dilanjutkan dengan latihan di lapangan selama beberapa bulan di bawah pengawasan para senior.

Untuk bisa mengisi posisi di BaliTV, seorang calon jurnalis harus berusia maksimal 25 tahun dan lulus serangkaian tes untuk menguji kemampuan menulis berita, mempresentasikan berita, kemampuan fotografi dan videografi, serta wawasan dan pengetahuan umum. Latar belakang pendidikan minimal telah mengantongi gelar sarjana strata satu (S1) dari jurusan apa saja.

Tantangan yang sedang dihadapi BaliTV dari sisi sumber daya manusia, khususnya jurnalis adalah perihal regenerasi yang kurang berjalan baik.BaliTV saat ini setidaknya butuh lima orang jurnalis baru untuk ditempatkan di sejumlah kabupaten di Pulau Bali.Begitu pula dengan jurnalis-jurnalis untuk ditempatkan di berbagai provinsi di Indonesia.

BandungTV merupakan televisi lokal Kota Bandung yang tampaknya tidak terlalu memrioritaskan keberadaan jurnalis. Rekruitmen BandungTV untuk semua posisi, bukan hanya jurnalis, dilakukan via iklan di BandungTV sendiri. Posisi jurnalis dibutuhkan jika ada jurnalis yang mengundurkan diri dari Bandung $T V$.

Syarat untuk menjadi jurnalis di BandungTV tidak terlalu ketat. Pendidikan calon jurnalis minimal D3, dari latar belakang keilmuan apapun. Pendidikan jurnalistik tidak dipentingkan, yang penting memiliki wawasan yang luas, mau belajar, dan memiliki kepribadian yang baik. Selain itu calon diharapkan memiliki kemampuan berbahasa Sunda, minimal bahasa pergaulan.

Untuk Standar Kompetensi Wartawan (SKW), BandungTV belum mengikuti standar yang dikeluarkan oleh Dewan Pers, tetapi masih mengacu kepada standar kompetensi internal. Hal tersebut terjadi mungkin karena program berita belum menjadi prioritas di BandungTV.

Jurnalis muda yang ada di industri televisi dipandang masih belum bisa dilepas ke lapangan secara mandiri. Umumnya jurnalis di industri televisi yang berskala nasional masih harus mengikuti pelatihan kejurnalistikan yang disediakan secara internal oleh masing-masing televisi. Pelatihan ini memiliki rentang yang berbeda-beda, mulai dari tiga bulan hingga enam bulan. Pelatihan ini juga menjadi ajang penilaian bagi jurnalis muda. Jika nilai hasil pelatihan ini rendah, maka peserta pelatihan akan diwawancara kembali.

Kondisi jurnalis muda di stasiun televisi lokal seperti BaliTV dan BandungTV berbeda dengan industri televisi skala nasional. Di sini, profesi jurnalis termasuk profesi yang tidak diinginkan. Di Bali, profesi yang menarik adalah profesi yang berkaitan dengan kepariwisataan, sedangkan di BandungTV, divisi pemberitaan bukanlah divisi yang ditargetkan untuk dijual kepada pengiklan. Hal ini berpengaruh terhadap penerimaan jurnalis muda. Di BaliTV, karena kesulitan mencari jurnalis baru, maka pengelola media harus memindahkan staf dari divisi lain untuk menjadi jurnalis. Tentu saja 
masalah ini berdampak bagi produktivitas kerja, baik kualitas maupun kuantitas.

Jika dilihat berdasarkan kuantitas, maka lulusan pendidikan tinggi jurnalistik hanya mampu memenuhi sebagian. Pertama, karena memang jumlah lulusannya sedikit sedangkan pasar ini sedemikian terbuka. Kedua, banyak lulusan jurnalistik yang kemudian memilih untuk tidak menjadi jurnalis karena berbagai pertimbangan. Mereka memilih untuk bekerja di bidang lain seperti menjadi petugas hubungan masyarakat, peneliti, bekerja di bagian pemasaran, dan lain-lain.

Dari sisi kemampuan, secara garis besar tidak banyak perbedaan keterampilan jurnalistik yang ditunjukan oleh lulusan yang bukan berasal dari pendidikan jurnalistik dan lulusan dari pendidikan jurnalistik di media TV. Namun diakui bahwa diawal penerimaan jurnalisbaru untuk TV, lulusan pendidikan tinggi jurnalistik lebih menguasai etika dan aturan-aturan yang berkaitan dengan dunia jurnalistik.

Dari sisi daya juang, hampir tidak ada perbedaan yang signifikan dari semua lulusan. Hal lain yang menjadikan lulusan dari pendidikan tinggi jurnalistik berbeda dengan lulusan lain adalah, keluhan dari khalayak. Bisa dilihat, bahwa keluhan terhadap jurnalis TV yang masuk ke Dewan Pers dan Komisi Penyiaran Indonesia tidak ada yang berasal dari lulusan pendidikan tinggi jurnalistik. Bagaimanapun juga, kurikulum jurnalistik harus selalu mengikuti perkembangan zaman. Perkembangan teknologi, kondisi sosial, politik, ekonomi dan berbagai hal lain juga selalu berubah.

Kompas.com menerima kandidat jurnalis dari pendidikan D3 maupun S1. Tidak menutup kemungkinan Kompas.com juga menerima kandidat dari pendidikan S2. Namun Kompas. com tidak menyaratkan bahwa yang melamar haruslah yang telah lulus pendidikan tinggi. Baik fresh graduate maupun yang masih dalam proses penyusunan Tugas Akhir, Skripsi, atau Thesis boleh dan mungkin diterima sebagai jurnalis baru.

Kelemahan utama para jurnalis muda yang melamar ke Kompas.com, kebanyakan menganggap bahwa sebagai jurnalis online mereka tidak perlu ke lapangan. Cukup di kantor menggunakan internet. Juga ketika mereka diberi tugas untuk peliputan travelling, yang ada dalam pemahaman mereka adalah bahwa mereka hanya bertugas jalan-jalan. Belum ada kesadaran bahwa sebagai jurnalis online mereka harus liputan di tempat pada saat itu juga.

Kompas.com tidak mensyaratkan pendidikan jurnalistik sebagai kriteria utama. Justru berdasarkan pengalaman, lulusan bidang ilmu di luar jurnalistik lebih banyak diterima di Kompas.com dibandingkan lulusan ilmu jurnalistik. Tidak ada jaminan bahwa lulusan jurnaslitik lebih berkualitas dibandingkan lulusan bidang ilmu lain. Bahkan, Kompas.com menilai adanya bidang ilmu yang beragam malah lebih menguntungkan.

Kompas.com menilai, cara berjurnalisme di internet ternyata berbeda sekali dengan caracara jurnalistik di media-media mainstream. Karena itu,Kompas.com merasa hal-hal yang berhubungan dengan penggunaan internet dalam jurnalistik penting untuk dimasukkan dalam kurikulum pendidikan jurnalistik, karena banyak praktik yang diperlukan dalam berjurnalistik di internet tidak terakomodasi oleh pakem-pakem jurnalistik lama. Selain itu Kompas.com menilai, dalam kurikulum pendidikan jurnalistik harus ada satu subjek yang memungkinkan mahasiswa melakukan peliputan topik khusus, misalnya meliput khusus topik ekonomi, hukum, atau olahraga.

Kompas.com juga berharap, lulusan pendidikan jurnalistik adalah orang-orang yang matang dalam hal penulisan. Pengetahuan teknologi terbaru dan teknik dasar juga diperlukan. Setidaknya jurnalis muda tahu secara teknis kualitas bahan berita yang layak untuk media online.Kompas.com juga berharap pendidikan jurnalistik dapat menghasilkan lulusan yang multitalented, artinya lulusan yang mampu melakukan berbagai liputan dalam berbagai format. Tantangan ke depan adalah: Convergent Newsroom.

Kualifikasi profesional dalam perekrutan wartawan adalah langkah pertama untuk membuat produk jurnalistik yang baik dan bertanggung jawab. Para pelaku media, yang menjalankan bisnis media, pasti adalah para oportunis yang berusaha keras untuk membuat bisnis mereka menguntungkan. Oleh karena itu, menghasilkan produk jurnalistik berkualitas sebagai bagian penting dari media tidak dapat dianggap sebagai cara yang mudah.

Kredibilitas menjadi faktor utama dalam mempertahankan eksistensi media di kalangan 
masyarakat. Untuk menjaga kredibilitas, profesionalisme sumber daya manusia benar-benar diperlukan. Untuk melakukan itu, media harus memiliki pelatihan yang disesuaikan untuk memenuhi standar yang diinginkan. Langkah ini, tentu harus dilakukan pada tahap awal dari saat wartawan dalam proses perekrutan.

Sebagai contoh bagaimana profesionalisme dapat dideteksi sejak awal, Andreas Harsono, penulis A9ama SAYA adalah Jurnalisme, mengutip proses rekrutmen di The Philadelphia Inquirer. Wendel 'Sonny' Rawls, seorang wartawan senior yang dikenal sebagai pencari bakat jurnalis yang hebat, biasanya meminta para pelamar dalam proses rekrutmen untuk mengirimkan 10 artikel. Apa yang ia minta adalah berita, bukan berita khas (feature news). Setelah artikel diterima, ia akan membaca bagian utama dan tiga paragraf pertama. Jika kalimat dan bahasanya jelas dan mudah diserap, ia akan membaca tulisan tersebut sampai akhir. Ini merupakan langkah penting untuk menemukan apakah pemohon memiliki kemampuan untuk menghubungkan bagian utama dengan bagian akhir.Sonny jelas memiliki kemampuan untuk menilai kemampuan dan kredibilitas para pelamar dengan menggunakan metode ini. (Harsono, 2010: 93-96).

Ilustrasi tersebut menunjukkan bahwa media massa harus menaruh perhatian penuh dari tahap sangat awal untuk menjaga kualitas wartawan mereka, bahkan sebelum mereka benar-benar diterima oleh mereka. Media massa harus memiliki kemampuan untuk melihat potensi para pelamar. Selain itu, media harus menerapkan standar tertentu sehingga mereka dapat menyesuaikan kualifikasi yang dimiliki oleh pelamar dengan idealisme mereka untuk mempertahankan kredibilitas media.

Apabila melihat sistem rekruitmen dari media massa dalam penelitian ini, tampak bahwa mereka telah coba lakukan hal tersebut dengan menerapkan skill test dalam proses perekrutan mereka. Namun, dalam kenyataannya ada banyak pelanggaran terhadap ide-ide jurnalistik yang dilakukan oleh wartawan muda di lapangan Banyak pelanggaran yang mungkin terjadi karena kurangnya pengetahuan tentang prinsip-prinsip jurnalistik dan kode etik jurnalistik. Namun ternyata, didapat bahwa pengetahuan bukanlah satu-satunya alasan.

Dewan Pers Indonesia melakukan penelitian tentang hal ini dan menyimpulkan bahwa masalah utama dari pelanggaran prinsip-prinsip jurnalistik bukanlah kurangnya pengetahuan, tetapi juga karena rutinitas yang ketat yang harus dilakukan oleh wartawan. Banyak wartawan, diberi kewajiban untuk menulis sejumlah artikel dalam satu hari. Jadwal yang ketat ini membuat mereka sulit untuk meluangkan waktu melakukan verifikasi, wawancara ulang narasumber, atau bahkan untuk menulis ulang artikel. Hal ini terjadi terutama di media online seperti Kompas.com yang selalu meminta wartawan mereka untuk menulis lebih cepat dari media lainnya.

Masalah ini juga terjadi ketika wartawan harus menerapkan salah satu dari Kode Etik Jurnalistik, yaitu prinsip keadilan. Banyak wartawan tampaknya tidak menguasai prinsip ini dengan benar, terutama ketika mereka menulis judul berita. Kewajiban untuk membuat judul berita yang efisien dan menarik kadang-kadang hanya membawa wartawan ke dalam ambiguitas. Kadang-kadang wartawan terjebak dalam menilai sumber karena kesalahan penggunaan bahasa.

Dewan Pers memang telah memiliki ketentuan yang dikenal sebagai Standar Kompetensi Wartawan yang ditetapkan pada 26 Januari 2010. Namun, adanya sejumlah pengaduan dan pelanggaran menunjukkan bahwa Kode Etik Jurnalistik dan Standar Kompetensi Wartawan yang seharusnya diratifikasi oleh peraturan perusahaan media ternyata belum diterapkan secara optimal. Temuan ini tak lepas dari kebijakan media massa dalam menerapkan profesionalisme wartawan mereka.

Dari topik profesionalisme wartawan, menarik untuk diketahui: mengapa jurnalis muda yang bekerja di media massa menunjukkan sikap yang tidak sesuai dengan keinginan media? Apakah karena karakteristik medianya? Atau karena dari budaya mereka saat ini?

Jawabannya adalah keduanya. Para jurnalis muda dapat dikategorikan sebagai digital natives. Ini berarti mereka sudah akrab dengan peralatan digital dan fasilitas yang disediakan yang membuat hidup lebih mudah sejak mereka lahir. Kondisi ini dapat menjadi salah satu alasan mengapa para wartawan muda enggan pergi ke lapangan. Orang-orang muda ini biasanya lebih suka untuk berada di dunia mereka sendiri, yang dibuat oleh aplikasi digital 
yang disebut komunitas virtual.

Howard Rheingold menjelaskan komunitas virtual sebagai "the social aggregations that emerge from the Net when enough people carry on those public discussion long enough, with sufficient human feeling, to form webs of personal relationships in cyberspace." (Rheingold, 1993: 5) Beberapa media telah menggunakan tren ini di lingkungan kerja mereka. Dewan redaksi sudah menerapkan pertemuan virtual dan newsroom virtual. Menurut studi ini, jurnalis muda tidak merasa heran dengan kebijakan tersebut. Sebaliknya, berdasarkan pengamatan, mereka tampaknya menikmati lingkungan ini. Hal ini mungkin terjadi karena sifat dari budaya digital mereka. Namun, ini menjadi masalah, karena karya jurnalistik yang baik masih memerlukan praktek mengumpulkan informasi dari lapangan yang nyata, bukan hanya digital.

Dapat diasumsikan bahwa masalah yang paling penting adalah untuk membawa budaya jurnalis muda kembali ke realitas. Pada akhirnya diharapkan mereka akan peduli pada masalah sosial yang nyata di sekitar mereka, dan mudah-mudahan mereka akan lebih peduli kepada orang lain dalam lingkungan mereka.

Namun demikian, tidak mudah untuk mengubah sifat para digital natives. Generasi muda ini telah mengalami kemudahandan keasyikan dalam aplikasi digital. Menggunakan perangkat digital dan online bisa membuat mereka sangat kecanduan. Ini adalah keunikan dunia digital kita yang memang harus dihadapi. Hal yang bisa kita lakukan adalah menyesuaikan kehidupan kita sehari-hari dengan aplikasi digital ini. Budaya baru komunikasi harus diantisipasi, tidak hanya oleh profesional bisnis atau industri media massa, tetapi juga oleh lembaga pendidikan yang berhubungan dengan generasi digital natives.

\section{SIMPULAN}

Dari hasil penelitian ini, dapat diambil simpulan bahwa media massa membutuhkan tenaga-tenaga muda untuk meneruskan kegiatan jurnalistiknya, namun mereka menghadapi kendala ketika berhadapan dengan karakteristik generasi muda sekarang yang seringkali berseberangan dengan etos kerja jurnalistik

Pada umumnya semua narasumber mengatakan bahwa Standar Kompetensi Wartawan
(SKW) itu penting untuk diimplementasikan. Artinya, ada sebuah keseragaman kebutuhan di seluruh media massa akan kualifikasi jurnalis secara umum.

Dari sistem seleksi jurnalis diketahui bahwa pendidikan jurnalistik tidak menjadi prioritas dalam merekrut jurnalis baru. Dari semua media massa yang menjadi objek penelitian, hanya Suara Surabaya FM dan PRFM yang secara ekplisit menyatakan bahwa lulusan pendidikan jurnalistik menjadi prioritas.

Dan kenyataan bahwa lulusan pendidikan jurnalistik tidak menjadi prioritas dalam perekrutan menggambarkan bahwa dunia kerja dibidang kejurnalistikan begitu terbuka. Namun pendidikan tinggi kejurnalistikan dianggap diperlukan karena untuk mencapai kondisi jurnalistik yang ideal perlu tetap ada pendidikan yang ideal. Kurikulum harus terus disempurnakan untuk mengangkat dan memotivasi pembangunan masyarakat, bukan sekedar menuruti kemauan pemilik media.

Di tahap ini, peneliti menyarankan bahwa narasumber dari industri media massa dan pembuat kurikulum pendidikan tinggi ilmu jurnalistik di Indonesia hendaknya mendukung penelitian ini dan memanfaatkan hasilnya. Hal ini kami sarankan mengingat betapa pentingnya pemetaan yang kami lakukan saat ini, agar menciptakan iklim profesional dalam dunia kewartawanan di Indonesia, sekaligus meningkatkan kualitas pendidikan tinggi ilmu jurnalistik di Indonesia menjadi kualitas yang mampu mendekatkan dunia kerja ke dunia akademik.

Pendidikan jurnalistik harus mampu memetakan kondisi jurnalis di berbagai daerah di Indonesia. Hal ini penting diketahui untuk menjembatani kesenjangan antara kemampuan jurnalis muda dengan Standar Kompetensi wartawan yang ditetapkan oleh Dewan Pers. Jika kesenjangan ini diketahui maka akan menjadi jembatan bagi pendidikan tinggi jurnalistik untuk ikut serta membina jurnalis muda di daerah.

\section{DAFTAR PUSTAKA}

Harsono, A. (2010). Agama saya adalah jurnalisme. Jakarta: Kanisius

Kovach, B. \& Rosenthiel, T. (2001). The elements of journalism, what newspeople 
should know and the public should expect. New York: Crown Publisher.

Rheingold, H. (1993). The virtual community: homesteading on the electronic frontier. Ontario Canada: Addison-Wesley Publishing Company.

SET, Y. (2010). Hasil penelitian problem penegakan etika dan profesionalisme media berdasarkan pengalaman dewan pers. Sudibyo, A. (2001). Kabar-kabar kebencian. Jakarta: Institut Studi Arus Informasi (ISAI) http://www.dewanpers.or.id/page/pengaduan/ laporan

http://www.dewanpers.or.id/page/kebijakan/ peraturan 